\title{
Bir Çocukta Eoznofilik Granülom
}

\section{Eosinophilic Granuloma of a Child}

\author{
Özgür Demir ${ }^{1}$, Erol Öksüz ${ }^{1}$, Fatih Ersay Deniz ${ }^{1}$ \\ 1 Gaziosmanpaşa University, Department of Neurosurgery, Tokat, Turkey.
}

OZET

ABSTRACT

Eoznofilik granüloma Langerhans hücreli histiyositozisin bir parçasıdır. O sıklıkla kranial kemik tutulumu yapan nadir, iyi huylu bir kemik tümörüdür. Genellikle hastalar 5 ile 15 yaş arasındadırlar. Eoznofilik granüloma lezyonları kendiliğinden kaybolabilir. Ağrılı lezyonlar; kemoterapi, radyoterapi, cerrahi küretaj veya lokal kortizon infüzyonu ile tedavi edilebilirler. Altı yaşında bir kız çocuğu kliniğimize, sağ paryatal bölgede son 2 aydır ağrısı ve boyutu giderek artan ağrılı bir şişlik şikayeti ile başvurdu. Radyolojik bulgular; sağ paryatalde intra ve ekstra kranial uzanımları olan litik bir lezyonu gösterdi. Hastanın tümörü gros total eksize edildi ve kemik defektine kranioplasti uygulandı. Hastaya herhangi bir destek tedavi verilmedi. Tümörün histopatolojisi Langerhan hücreleri ile karışık kronik selüler infiltratlar ile eoznofilleri gösterdi. Bulgular eoznofilik granüloma ile uyumluydu. Bu hastalık için belirlenmiş bir tedavi yöntemi yoktur. Tedavi şekli hastalığın yaygınlığına ve semptomlara göre değişebilir. Biz intrakranial uzanımı olan ağrılı lezyonlarda cerrahi eksizyonu öneriyoruz.

Anahtar Kelimeler: Eoznofilik granülom
Eosinophilic granuloma is part of Langerhans' cell histiocytosis. It is a rare, benign bone tumor, often involving the head bones. Most patients present between 5 and 15 years of age. Lesions of eosinophilic granuloma may disappear spontaneously. Painful lesions can be treated with radiotherapy, chemotherapy, surgical curettage of the tumor or local infusion of cortisone. A six year old girl presented to our clinic with severe painful swelling on the right parietal region with a gradual increase in size and frequent episodes of headache for 2 months. Radiological findings demonstrated right parietal cranial lytic lesion with intra and extracranial extension. The patient was treated with gross total excision of tumor and cranioplasty without any adjuvant therapy. Histopathology of the tumor showed cellular components of Langerhan' cells admixed with chronic cellular infiltrate and eosinophils. Findings were consistent with eosinophillic granuloma. The patient recovered well with no known recurrence till date. There is no definitive treatment option for this disorder. Treatment option may be changed depending on the extent of the disease and the symptoms. We recommend surgical excision in the presence of intracranial extension of painful lesion.

Keywords: Eosinophilic granuloma.
Corresponding Author: Özgür DEMIR

Address: Gaziosmanpaşa University, Department of

Neurosurgery, Tokat, Turkey;

\section{Başvuru Tarihi/Received: 17-11-2015}

Kabul Tarihi/Accepted: $\quad$ 03-03-2016

E-mail: cerendemir40@gmail.com 
Introduction

Eosinophilic granuloma, is a relatively rare disorder of unknown etiology, probably arising from circulating myeloid dendritic cells. It is most common in children 5 to 10 years of age . Presentation of eosinophilic granuloma with a single (monostotic) bone lesion is more common than multiple (polyostotic) bone lesions. The most commonly involved bone is the skull in children. Clinically, patients with eosinophilic granuloma of the bone present with painful swelling at the affected bony site (1). Plain radiography and computerized tomography (CT) classically have a punchedout, lytic appearance. Eosinophilic granuloma is typically "hot" on radionuclide bone scans. Radionuclide bone scan can detect multiple bone lesions. Magnetic resonance imaging (MRI) scans with contrast can demonstrate enhancement of the lesion and often soft tissue components with intra and extracranial parts (2). Histologic confirmation is necessary for diagnosis since the clinical and imaging characteristics of eosinophilic granuloma overlap with several other disease processes, including malignancy, infection, and other benign tumors of bone. There is no universally accepted protocol for the treatment of eosinophilic granuloma. Strategies have utilized observation only, surgical curettage, radiation therapy, steroid injections, and chemotherapy (3).

\section{Case report}

A 6-year-old girl presented with a tender, painful swelling of the head. It was located

on the right parietal region and had a diameter of about $3 \mathrm{~cm}$. The patient sensed a gradual increase in size and frequent episodes of headache for 2 months. Plain radiography and CT showed a punched-out, lytic lesion on the right paretal region (Figure 1, 2). MRI with and without contrast demonstrated an irregular lesion with intra-and extracranial extension that had an intermediate signal intensity and demonstrates marked enhancement. The base of the lesion rested on the dura mater provoking menigeal enhancement (Figure 3). Whole body bone scintigraphy showed no bone lesion except right parietal region (Figure 4). Her blood examinations revealed no pathological findings. A gross total excision of the lesion and the surrounding healthy bone tissue borders of $1 \mathrm{~cm}$ was performed. It was perforating the whole diploe and part of the dura mater. We excised a piece of a dura mater where the lesion adhered. Then we performed cranioplasty with titanium patch. Histopathological examination of the lesion showed eosinophillic granuloma with cellular components of langerhan cells, chronic cellular infiltrate and eosinophils. Limited infiltration was detected in the surrounding healthy bone tissue (Figure 5). We did not perform any adjuvant therapy for the patient. She recovered well. Control CT of the brain depicted no further recurrence after one year (Figure 6).

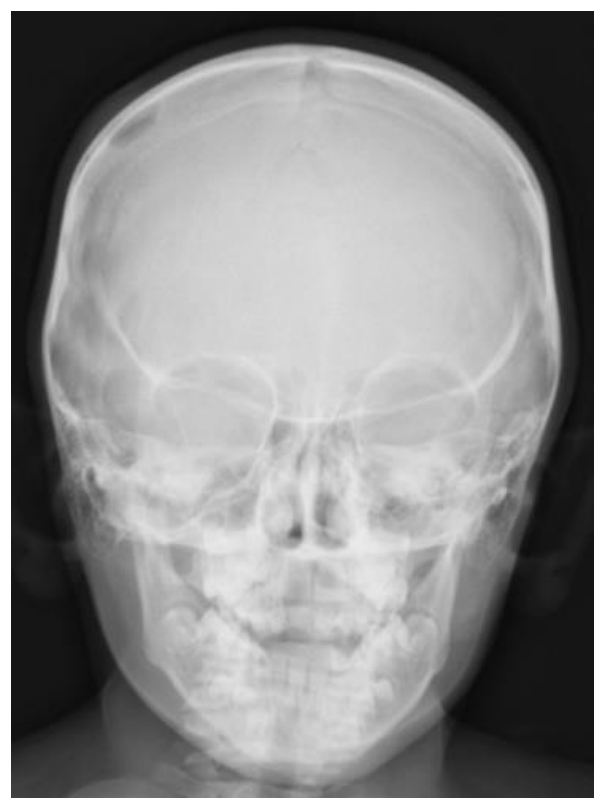

Figure 1: Plain radiography showed a punched-out, lytic lesion on the right paretal region. 


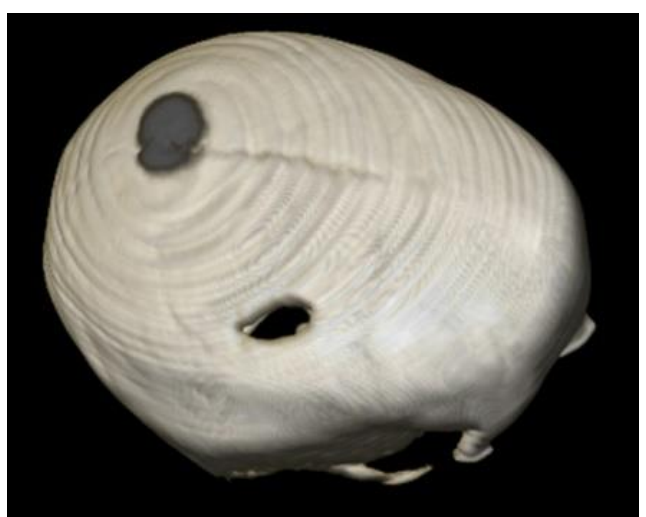

Figure 2: CT clearly showed bone destruction

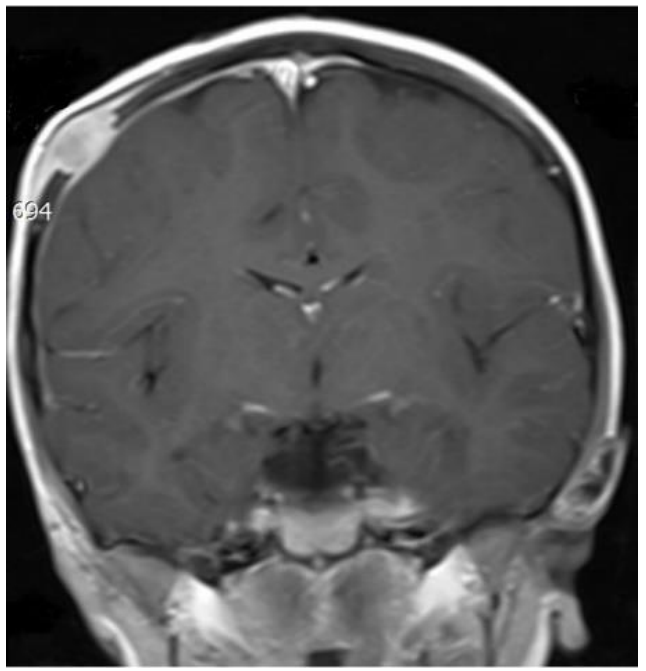

Figure 3: MRI showed an irregular lesion with intraand extracranial extension that had an intermediate signal intensity and demonstrates marked enhancement. The base of the lesion rested on the dura mater provoking menigeal enhancement.

\section{Discussion}

Eosinophilic granuloma is one of the rarest bone tumors representing less than $1 \%$ of all bone tumors. In $90 \%$ of the reported cases it occurs in children under the age of ten. There is a certain predilection to males. It usually presents in the parietal region of skull (4). Our case is consistent with the literature except the gender. Our patient was six years old. Tumor was located in the parietal region.

The blood tests show an elevation of leucocytes and eosinophils in approximately $7 \%$ of the cases with eosinophilic granuloma. Erythrocyte sedimentation rate is generally over the normal levels (5). In the presented case, blood tests of the patient were in the normal range.

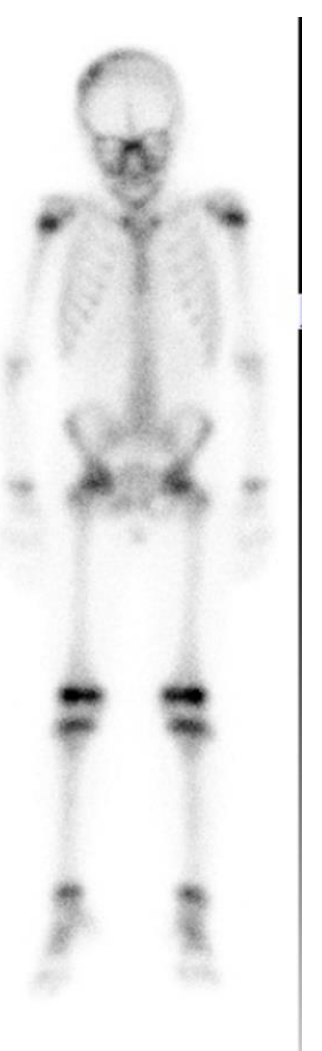

Figure 4: Bone scintigraphy showed no bone lesion except right parietal region. Scintigraphy showed increased osteoblastic activity on the right parietal region.

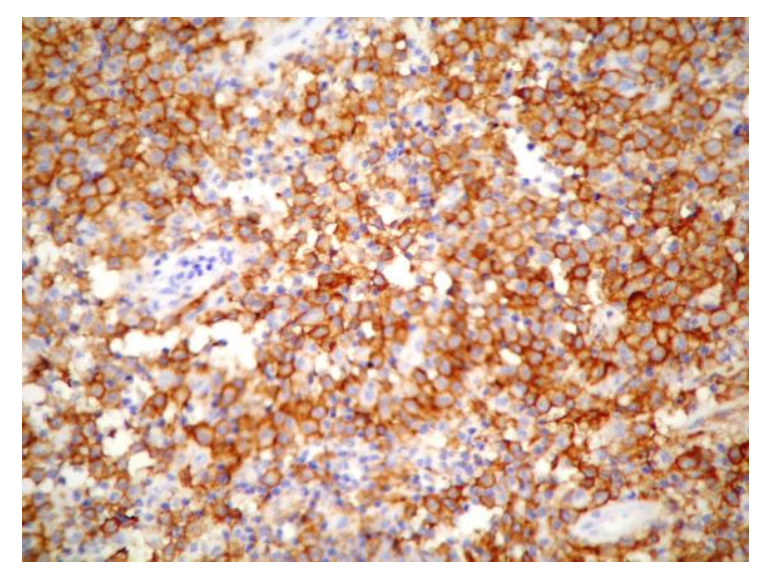

Figure 5: Histopathology showed cellular components of langerhan cells admixed with chronic cellular infiltrate and eosinophils.

Plain radiograph and $\mathrm{CT}$ reveales size and borders of osteolytic oval bone defects. MRI demonstrates the exact size and borders of 
the tumoral soft tissue. In this presented case, MRI showed intra and extra-cranial extension of the tumoral tissue. Therefore MRI was the most important radiological examination in determining the treatment strategy. It is important to detect the presence of multiple bone lesions in eosinophilic granuloma (6). We used radionuclide bone scan to detect an other foci point. Radionuclide bone scan didn't show any other bone lesion in this case.

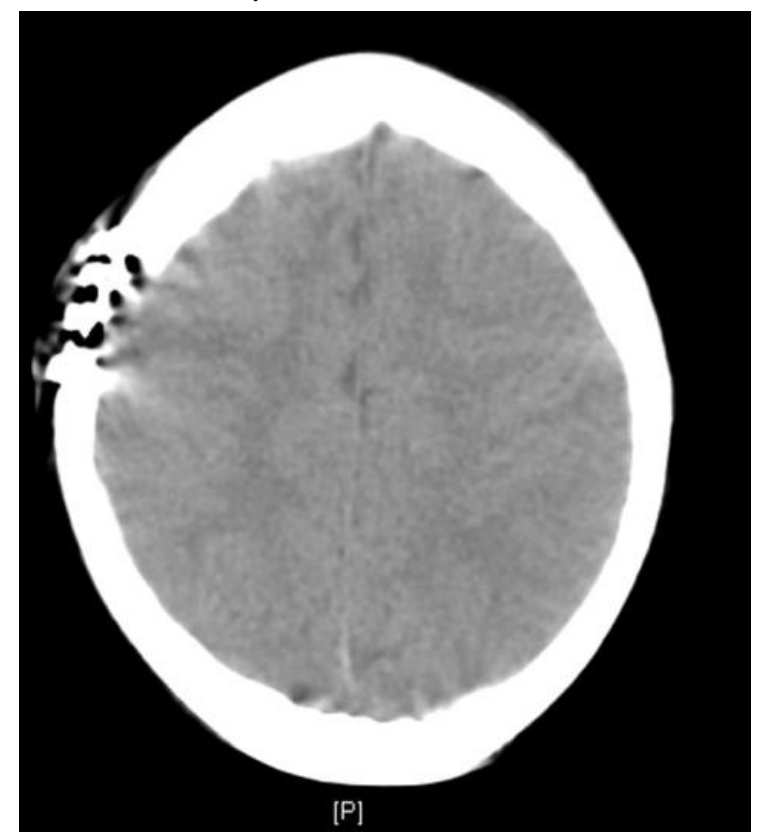

Figure 6: Control CT showed no recurrence in the postoperative period of one year.

Venous lake, meningocele, cranium bifidum, arachnoid granulation, parietal foramen, epidermoid cyst, hemangioma, cholesteatoma, fibrous dysplasia, metastasis, surgical defect, and osteomyelitis should be considered in the differential diagnosis of eosinophilic granuloma (7). Therefore definitive diagnosis of eosinophilic granuloma based on immunohistochemistry and histopathology. A unique cell, the Langerhans cell is diagnostic. Eosinophils, lymphocytes, fibroblasts and foam cells may be also found but none of them is pathognomonic. Biopsy of suspicious lesions and staining for CD1a, antilangerin (CD207) or S-100 protein is needed in order to confirm the diagnosis (8). In this case; histopathological examination of the lesion showed eosinophillic granuloma and was confirmed with staining for CD1a and S-100 protein.

Clinically, eosinophilic granuloma can be asymptomatic or present as local swelling, pain or tenderness. This may cause neurological symptoms such as numbness, limping, fracture, loosening of teeth, otitis media or exopthalmos, depending on the location of the tumor (9). Our patient had local swelling and tenderness on the right paretal region. The patient had also gradually increased headache. She had no any other neurological symptom.

There is no well defined treatment strategy for eosinophilic granuloma. The strategy may be changed depending on the extent of the lesions and the symptoms. However, given the relatively favorable prognosis of localized bone eosinophilic granuloma in non-"central nervous system (CNS)-risk" areas without systemic involvement, a minimally aggressive approach is most often advocated. These approaches are observation only, local or systemic steroid injections. Sphenoid, orbital, ethmoid, or temporal bones were shown as CNS-risk areas in some studies. These solitary skull lesions are often treated with curettage. Radiation therapy and chemotherapy can be used for the patients with systemic involvement and multiple bone lesions (10). According to our opinion; some skull lesions in anywhere may have an accompanying mass that impinges on the dura, with a risk for CNS disease. In the presented study; there was intrcranial extension of tumor which impinged on the dura. We preferred surgical excision because of the risk for occurrence of neurological symptoms. Our patient underwent surgery without any adjuvant therapy. Systemic evaluation and follow-up showed no recurrence till date. 
An informed consent form was obtained from the patient.

\section{References}

1) Rawlings CE 3rd, Wilkins RH. Solitary eosinophilic granuloma of the skull. Neurosurgery 1984;15(2): 155-61.

2) Howarth DM, Gilchrist GS, Mullan BP, Wiseman GA, Edmonson JH, Schomberg PJ. Langerhans cell histiocytosis: Diagnosis, management and outcome. Cancer. 1999; 85(10): 2278-90.

3) Martinez-Lage JF, Bermudez M, MartinezBarba E, Fuster JL, Poza M: Epidural hematoma from a cranial eosinophilic granuloma. Child's Nerv Syst 2002; 18(1-2): 74-6.

4) Laman JD, Leenen PJ, Annels NE, Hogendoorn PC, Egeler RM. Langerhans-cell histiocytosis 'insight into DC biology' Trends Immunol 2003; 24(4): 190-6.

5) Smith JH, Fulton L, O'Brien JM. Spontaneous regression of orbital Langerhans cell granulomatosis in a three-yearold girl. Am J Ophthalmol 1999; 128(1): 119-21.

6) Guyot-Goubin A, Donadieu J, Barkaoui M, Bellec S, Thomas C, Clavel J. Descriptive epidemiology of childhood Langerhans cell histiocytosis in France, 2000-2004. Pediatr Blood Cancer 2008; 51(1): 71-5.

7) Azouz EM, Saigal G, Rodriguez MM, Podda A. Langerhans' cell histiocytosis: pathology, imaging and treatment of skeletal involvement. Pediatr Radiol 2005; 35(2): 103-15.

8) Schmitz L, Favara BE. Nosology and pathology of Langerhans cell histiocytosis. Hematol Oncol Clin North Am 1998; 12(2): 221-46.

9) Ghanem I, Tolo VT, D'Ambra P, Malogalowkin $\mathrm{MH}$. Langerhans cell histiocytosis of bone in children and adolescents. J Pediatr Orthop 2003; 23(1): 124-30.

10) Cochrane LA, Prince $M$, Clarke $K$. Langerhans' cell histiocytosis in the paediatric population: presentation and treatment of head and neck manifestations. J Otolaryngol 2003; 32(1): 33-7. 